\title{
Cytomorphometric Analysis of Cervical Papanicolaou Smear for Females with Gynecological Clinical Complaints
}

\author{
Sahar Elderdiri Osman ${ }^{1}$, Ehab Mohammed Elmadenah ${ }^{2}$, Osman Mohammed Elmahi ${ }^{3}$, \\ Mubarak Elsaeed Alkarsani ${ }^{3}$, Lienda Bashier Eltayeb ${ }^{4}$, Hisham Ali Waggiallah ${ }^{4 *}$ \\ ${ }^{1}$ Department of Histopathology and Cytology, Medical Laboratory Science Program, \\ Alfajr College of Science and Technology, Khartoum, Sudan \\ ${ }^{2}$ Department of Hematology, Faculty of Medical Laboratory Science, \\ Dongola University, Aldabbah, Sudan \\ ${ }^{3}$ Department of Histopathology and Cytology, Faculty of Medical Laboratory Sciences, \\ Karary University, Khartoum, Sudan \\ ${ }^{4}$ Department of Medical Laboratory Science, College of Applied Medical Science, \\ Prince Sattam bin Abdulaziz University, Al-Kharj, Saudi Arabia
}

\begin{abstract}
Background: Limited information is provided on the quantitative cytomorphometric study of the cervical Pap test. The cervical Pap test is an important screening program for cervical cancer. A quantitative cytomorphometric examination of cervical Pap is used to accurately identify precancerous and cancerous lesions early and to reduce the occurrence and avoidance of invasive cancer. This study was aimed to assess the cytomorphological parameters (nuclear diameter [ND], cytoplasm diameter [CD], and nuclear-to-cytoplasmic ratio [N/C ratio]) of squamous epithelial cells from a cervical Pap smear.

Methods and Results: A prospective study was performed on 142 consecutive cervical Pap smears from women with gynecological clinical complaints. The ND and CD were determined by the Optika optical microscope camera using a digitizer cursor in both axes. The final images were taken with an X40 magnification. The ND, CD, and the N/C ratio were then measured and expressed in micrometers.

The women were classified into 5 age groups: $5(3.5 \%)$ in the age group of $<19$ years, $46(32 \%)$ in the $20-29$ group, $67(47.2 \%)$ in the 30-39 group, $23(16.2 \%)$ in the 40-49 group, and 1(0.7\%) woman was over age 50. There were no significant differences in the N/C ratio of superficial cells between age groups. The ND, CD, and the N/C ratio were significantly higher in women with clinical complaints than in women without clinical complaints

Conclusion: Cytomorphometic analysis might assist in the identification of cellular alterations due to gynecological diseases and increase the sensitivity and accuracy of the Pap smear technique.(International Journal of Biomedicine. 2021;11(1):46-49.)
\end{abstract}

Key Words: cytomophometry $\bullet$ Pap smear $\bullet$ nuclear diameter $\bullet$ cytoplasm diameter $\bullet$ nuclear-to-cytoplasm ratio

For citation: Osman SE, Elmadenah EM, Elmahi OM, Alkarsani ME, Eltayeb LB, Waggiallah HA. Cytomorphometric Analysis of Cervical Papanicolaou Smear for Females with Gynecological Clinical Complaints. International Journal of Biomedicine. 2021;11(1):46-49. doi:10.21103/Article11(1)_OA9

\section{Introduction}

A Pap test is an important screening procedure for cervical cancer. The identification of precancerous lesions by the Pap test decreases the occurrence of precancerous lesions and avoids the development of invasive cancer. ${ }^{(1)}$ The background of the Pap test, developed by George Papanicolaou, the "father of cytology," has shown that specific cervix cells have morphological characteristics that can be used to diagnose carcinoma. Cells are obtained from the cervix, the lower part of the uterus protruding into the vagina. (2) $^{(2)}$ The most mature squamous cell is considered a superficial cell, typically polygonal (45-50 $\mu \mathrm{m}$ in diameter), with a pyknotic nucleus (5-6 $\mu \mathrm{m}$ in diameter). Intermediate cells are also mature squamous 
cells, typically polygonal (20-40 $\mu \mathrm{m}$ in diameter), with vesicular nucleus dimensions of 6-9 $\mu \mathrm{m}$ in diameter, and sometimes binucleated. The immature cells are named parabasal and basal cells, the parabasal cells are circular or oval rather than polygonal (15-30 $\mu \mathrm{m}$ in diameter), the nucleus is variable in size and typically larger than that of the intermediate cell. Parabasal and basal cells are not normally examined because the Pap test does not scrape off the entire thickness of the epithelium, just a few upper layers. ${ }^{(3)}$ Exfoliative cytology is focused on epithelial tissue physiology. Usually, the epithelium is routinely exfoliated, and cell surface and thickness loss are permanent. ${ }^{(4)}$ Ordinary epithelial cells are coherent in nature, but they shed or exfoliate as they mature. During infection and malignancies, exfoliation is excessive and epithelial cell morphology varied. ${ }^{(5)}$ Cytomorphometry is a quantitative approach focused on the calculation of cytomorphological parameters, including the nuclear diameter (ND), cytoplasm diameter (CD), and the nuclear-to-cytoplasmic ratio (N/C ratio), which may improve the efficiency of the cytology.(6) Most of the published research addresses cytomorphological analysis for buccal smear ${ }^{(7,8)}$ or morphometric study for histological samples of the cervix; ${ }^{(9)}$ few studies discuss cytomorphological investigation for the Pap smear. The current research was therefore intended to evaluate the quantitative analysis for the cytomorphological parameters of the exfoliative, epithelial squamous cell in the cervical Pap smear.

\section{Materials and Methods}

A prospective study was performed on 142 consecutive cervical Pap smears from women with gynecological clinical complaints. The scraped materials were taken with a cytospatula, smeared onto a glass slide, and immediately fixed in $95 \%$ ethyl alcohol. Subsequently, the smears were stained by the Papanicolaou staining technique.

\section{Papanicolaou staining method}

Slides were dehydrated by a descending concentration of alcohol $(95 \%, 70 \%)$ and distilled water for 3 minutes each. They were treated with Mayer's Hematoxylin for 5 minutes for nuclear stain and blued for 10 minutes in flowing tap water. The smears were counterstained with orange G6 for 5 minutes, differentiated in $95 \%$ ethanol for 10 seconds, then treated with Eosin EA50 for cytoplasmic stain for 5 minutes and again differentiated in $95 \%$ ethanol for 10 seconds. Finally, the smears were dehydrated through ascending concentration of alcohol $(70 \%, 95 \%, 100 \%)$ for 3 minutes each, cleared in xylene, and mounted in Distrene Polystryne Xylene. The cells were examined by using X40 objective lenses. ${ }^{(10)}$

\section{Cytomorphometric analysis}

Ten clearly defined cells with good staining were chosen by systematic sampling stepwise by shifting the microscope stage in a $\mathrm{Z}$ shape from left to right in order to avoid measuring the same cell again. Any folded, clumped, or distorted nucleus or cell was avoided in each smear. The superficial, intermediate and parabasal cells were established by morphology and staining characteristics. The ND and CD were determined by the Optika optical microscope camera using a digitizer cursor in both axes. The final images were

taken with an X40 magnification. The ND, CD and N/C ratios were then measured and expressed in micrometers. Quality management measures were adopted during the collection and processing of samples.

Statistical analysis was performed using the statistical software package SPSS version 20.0 (IBM Corp., Armonk, N.Y., USA). Continuous variables were presented as mean \pm standard deviation (SD). Means of 2 continuous normally distributed variables were compared by independent samples Student's t-test. Multiple comparisons were performed with one-way ANOVA. The frequencies of categorical variables were compared using Pearson's chi-squared test. A value of $P \leq 0.05$ was considered significant.

The ethics and research committee approved the study, and consent forms were obtained from all patients prior to procedures.

\section{Results}

A total of 142 smears from women aged from 16 to 49 years were examined. The women were classified into 5 age groups: $5(3.5 \%)$ in the age group of $<19$ years, $46(32 \%)$ in the $20-29$ group, $67(47.2 \%)$ in the $30-39$ group, $23(16.2 \%)$ in the 40-49 group, and $1(0.7 \%)$ woman was over age 50 . Unsatisfactory smears $(\mathrm{n}=14)$ were excluded from the study. The quantitative cytomorphological analysis is shown in Table 1, Figure 1, and Figure 2.

\section{Table 1.}

Cytomorphometric parameters ( $\mu m)$ in superficial (s) and intermediate (i) cells

\begin{tabular}{|l|c|c|c|c|}
\hline Type of cells & $\mathrm{n}$ & Minimum & Maximum & Mean $\pm \mathrm{SD}$ \\
\hline $\mathrm{NDs}$ & 128 & 2.2 & 9.00 & $4.9 \pm 1.7$ \\
\hline $\mathrm{CDs}$ & 128 & 17.2 & 62.00 & $37.5 \pm 10.6$ \\
\hline $\mathrm{N} / \mathrm{Cs}$ & 128 & 0.05 & 0.24 & $0.1 \pm 0.03$ \\
\hline $\mathrm{NDs}$ & 117 & 3.0 & 18.60 & $6.9 \pm 2.6$ \\
\hline $\mathrm{CDi}$ & 117 & 13.6 & 57.40 & $32.2 \pm 10.1$ \\
\hline $\mathrm{N} / \mathrm{Ci}$ & 117 & 0.1 & 0.57 & $0.23 \pm 0.07$ \\
\hline $\mathrm{NDi}$ & 5 & 6.0 & 10.00 & $8.0 \pm 1.6$ \\
\hline $\mathrm{CDi}$ & 5 & 23.0 & 35.00 & $29.0 \pm 5.3$ \\
\hline $\mathrm{N} / \mathrm{Ci}$ & 5 & 0.9 & 0.43 & $0.9 \pm 0.1$ \\
\hline
\end{tabular}

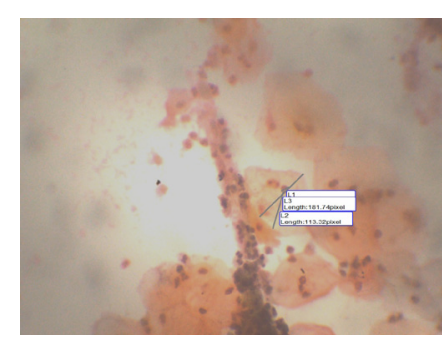

Fig. 1. Cervical Pap smear. Fig. 2. Cervical Pap smear. Measuring the $C D$ and $N / C$ ratio Measuring the $N D$ and $N / C$ ratio using OPTIKA software. using OPTIKA software.

There were no significant differences in the N/C ratio of superficial and intermediate cells between age groups 
(Table 2). The ND, CD, and the N/C ratio were significantly higher in women with clinical complaints than in women without clinical complaints (Table 3 ). There were significant differences in $\mathrm{ND}, \mathrm{CD}$, and $\mathrm{N} / \mathrm{C}$ ratio according to type of clinical complaints (Table 4).

Table 2.

The N/C ratio for superficial and intermediate cells according to the age groups

\begin{tabular}{|c|c|c|c|c|c|c|}
\hline $\begin{array}{c}\text { Type of } \\
\text { cells }\end{array}$ & $\begin{array}{c}\text { Age group } \\
\text { (years) }\end{array}$ & $\mathrm{n}$ & Mean $\pm \mathrm{SD}$ & Minimum & Maximum & $P$-value \\
\hline \multirow{5}{*}{ Superficial } & $<19$ & 4 & $0.1 \pm 0.02$ & 0.09 & 0.14 & \\
\cline { 2 - 6 } & $20-29$ & 44 & $0.1 \pm 0.03$ & 0.05 & 0.24 & \multirow{5}{*}{0.39} \\
\cline { 2 - 6 } & $30-39$ & 60 & $0.1 \pm 0.03$ & 0.07 & 0.23 & \\
\cline { 2 - 6 } & $40-49$ & 20 & $0.1 \pm 0.03$ & 0.07 & 0.17 & \\
\hline \multirow{5}{*}{ Intermediate } & $<19$ & 4 & $0.2 \pm 0.09$ & 0.13 & 0.25 & \\
\cline { 2 - 6 } & $20-29$ & 38 & $0.2 \pm 0.08$ & 0.12 & 0.44 & \multirow{2}{*}{0.89} \\
\cline { 2 - 6 } & $30-39$ & 58 & $0.2 \pm 0.8$ & 0.14 & 0.57 & \\
\cline { 2 - 6 } & $40-49$ & 17 & $0.2 \pm 0.06$ & 0.14 & 0.38 & \\
\hline
\end{tabular}

\section{Table 3.}

Cytomorphometric parameters (CMP) according to routine Pap for women with or without clinical complaints

\begin{tabular}{|c|c|c|c|c|}
\hline Type of cells & CMP & $\begin{array}{c}\text { Clinical } \\
\text { complaints }\end{array}$ & Mean \pm SD & $P$-value \\
\hline \multirow{6}{*}{ Superficial cells } & \multirow{2}{*}{ ND } & Yes & $7.0 \pm 1.1$ & \multirow{2}{*}{0.001} \\
\hline & & No & $4.7 \pm 1.6$ & \\
\hline & \multirow{2}{*}{$\mathrm{CD}$} & Yes & $41.6 \pm 6.6$ & \multirow{2}{*}{0.081} \\
\hline & & No & $37.1 \pm 10.8$ & \\
\hline & \multirow{2}{*}{$\mathrm{N} / \mathrm{C}$ ratio } & Yes & $0.17 \pm 0.03$ & \multirow{2}{*}{0.003} \\
\hline & & No & $0.1 \pm 0.03$ & \\
\hline \multirow{6}{*}{ Intermediate cells } & \multirow{2}{*}{ ND } & Yes & $9.4 \pm 3.2$ & \multirow{2}{*}{0.002} \\
\hline & & No & $6.7 \pm 2.1$ & \\
\hline & \multirow{2}{*}{$\mathrm{CD}$} & Yes & $35.7 \pm 5.6$ & \multirow{2}{*}{0.306} \\
\hline & & No & $31.96 \pm 10.27$ & \\
\hline & \multirow{2}{*}{$\mathrm{N} / \mathrm{C}$ ratio } & Yes & $0.275 \pm 0.126$ & \multirow{2}{*}{0.047} \\
\hline & & No & $0.221 \pm 0.069$ & \\
\hline
\end{tabular}

\section{Table 4.}

Cytomorphometric parameters for superficial cells according to type of clinical complaints

\begin{tabular}{|l|c|c|c|c|}
\hline \multicolumn{1}{|c|}{ Superficial cell } & $\mathrm{n}=128$ & $\mathrm{ND}$ & $\mathrm{CD}$ & $\mathrm{N} / \mathrm{C}$ \\
\hline $\begin{array}{l}\text { Lower abdominal } \\
\text { pain with vaginal } \\
\text { discharge }\end{array}$ & 57 & $4.5 \pm 1.5$ & $36.3 \pm 11.7$ & $0.1 \pm 0.03$ \\
\hline Infertility & 38 & $5.4 \pm 1.6$ & $38.4 \pm 9.9$ & $0.5 \pm 0.02$ \\
\hline Fistula & 3 & $5.6 \pm 0.3$ & $44.1 \pm 7.9$ & $0.1 \pm 0.02$ \\
\hline Uterine fibroid & 3 & $5.7 \pm 2.3$ & $38.7 \pm 14.6$ & $0.2 \pm 0.03$ \\
\hline Irregular cycle & 12 & $4.2 \pm 1.4$ & $40.4 \pm 11.0$ & $0.1 \pm 0.02$ \\
\hline Routine Pap & 9 & $7.2 \pm 0.9$ & $41.9 \pm 6.9$ & $0.2 \pm 0.03$ \\
\hline Oophoritis & 3 & $4.5 \pm 2.1$ & $31.2 \pm 8.3$ & $0.1 \pm 0.1$ \\
\hline Syphilis & 2 & $2.8 \pm 0.0$ & $24.9 \pm 1.6$ & $0.1 \pm 0.02$ \\
\hline Polycystic ovaries & 1 & 3.20 & 25.8 & 0.124 \\
\hline$P$-value & & 0.001 & 0.28 & 0.001 \\
\hline
\end{tabular}

\section{Discussion}

Cytomorphometric testing or image processing of exfoliated cells has also been proposed as a main measure to the classification and identification of cell and nuclear variations in these cytological smears, indicating that this computer-assisted analysis of microscope images can improve the susceptibility of exfoliative cytology to early detection of oral cancer, as these techniques are reliable, accurate and precise. The Pap test is the most effective cancer screening test in the world, although it has a high incidence of false-negative results due to subjective interpretation.

The current research attempted to calculate the ND, CD, and $\mathrm{N} / \mathrm{C}$ ratios by computer-assisted, morphometric analysis in cervical exfoliative cytology using Optika software. In this study, there were no substantial differences in the N/C ratio of superficial cells between age groups, and this is inconsistent with previous studies conducted by Anuradha and Sivapathasundharam. ${ }^{(11)}$ Patel et al. ${ }^{(12)}$ observed that basal cells could only divide by a set of numbers; therefore, tissue renewal ability decreases with age, leading to aged cell accumulation. Cells that remain for a longer period of time contribute to the effects of various local environmental factors, which can be clarified by both estrogen and progesterone increase at puberty, accompanied by an increase and decrease in the uterine cycle stage. The level of these hormones declines at post-menopause. These hormones are responsible for the rise in $\mathrm{ND}, \mathrm{CD}$, and $\mathrm{N} / \mathrm{C}$ ratio. ${ }^{(11,12)}$

In our research, the ND and N/C ratio were statistically significant among women at routine Pap clinics and women with clinical complaints. This finding explains that most gynecological complaints relate to fertility hormones and later promote the growth, differentiation, and maturation of the squamous epithelium of the cervix..$^{(13)}$

A number of diseases, inflammation, and reactive conditions have contributed to a change in cell morphology. Many causes, such as cervicitis, have been accompanied by loss of cervical columnar cells, a typical aspect of the maturation process. As a result, sexually transmitted infections are hypothesized to encourage maturation through inflammation activation and subsequent cellular repair. In comparison, oral contraception has been associated with increased cervical ectopy (or less cervical maturation). Some have indicated that the presence of increased immaturity is due to hormonal contraception, which induces tissue edema and endocervical eversion. ${ }^{(13)}$ Rani et al. ${ }^{(14)}$ reported that cytomorphometry parameters were statistically significant between precancerous and cancerous Pap smears. Cigarette smoking is another potential influence because nicotine and its metabolites can be found in cervical mucus. ${ }^{(15)}$ Interestingly, both hormonal contraceptives and longtime smoking have been correlated with an induced risk of cervical cancer, ${ }^{(16,17)}$ and HPV infection is widespread in adolescents and young adults. ${ }^{(18)}$

In conclusion, it was evident that cytomorphometic analysis might assist in the identification of cellular alterations due to gynecological diseases and increase the sensitivity and accuracy of the Pap smear technique. 


\section{Limitations of the study}

Only 142 females participated in this research, so for further studies, the sample size should be expanded in order to improve the precision and accuracy of the findings by examining each of the gynecological problems and making associations with alterations in cervical squamous cells, while also taking into account age and other environmental factors.

\section{Acknowledgments}

This publication was supported by the Deanship of Scientific Research at Prince Sattam bin Abdulaziz University, Alkharj, Saudi Arabia.

\section{Competing Interests}

The authors declare that they have no competing interests.

\section{References}

1. Conceição T, Braga C, Rosado L, Vasconcelos MJM. A Review of Computational Methods for Cervical Cells Segmentation and Abnormality Classification. Int J Mol Sci. 2019 Oct 15;20(20):5114. doi: 10.3390/ijms20205114.

2. Safaeian M, Solomon D, Castle PE. Cervical cancer prevention--cervical screening: science in evolution. Obstet Gynecol Clin North Am. 2007 Dec;34(4):739-60, ix. doi: 10.1016/j.ogc.2007.09.004.

3. Cibas ES, Alonzo TA, Austin RM, Bolick DR, Glant MD, Henry MR, Moriarty AT, Molina JT, Rushing L, Slowman SD, Torno R, Eisenhut CC. The MonoPrep Pap test for the detection of cervical cancer and its precursors. Part I: results of a multicenter clinical trial. Am J Clin Pathol. 2008 Feb;129(2):193-201. doi: 10.1309/E63PQJJXWCDLWNHQ. 4. Wikström I, Lindell M, Sanner K, Wilander E. Selfsampling and HPV testing or ordinary Pap-smear in women not regularly attending screening: a randomised study. Br J Cancer. 2011 Jul 26;105(3):337-9. doi: 10.1038/bjc.2011.236. 5. Varghese C, Venkataraman K, Bhagwat S. Manual for Cytology. Manuals for Training in Cancer Control. India: Ministry of helth and Family Welfare; 2005:1-44.

6. Verma R, Singh A, Badni M, Chandra A, Gupta S, Verma R. Evaluation of exfoliative cytology in the diagnosis of oral premalignant and malignant lesions: A cytomorphometric analysis. Dent Res J (Isfahan). 2015 Jan-Feb;12(1):83-8. doi: 10.4103/1735-3327.150339.

*Corresponding author: Dr. Hisham Ali Waggiallah. Department of Medical Laboratory Sciences, College of Applied Medical Sciences, Prince Sattam bin Abdulaziz University. E-mail: hishamwagg30@hotmail.com
7. Elmahi OM, Alsammani NM, Mohammed Y, Eltayeb LB, Waggiallah HA. The Impact of Serum Ferritin on Exfoliated Cells Morphology from Buccal Mucosa among Iron Deficiency Anemia Patients: Morphometric Study. J Biochem Tech. 2020 May-Sep ;11(3):57-64.

8. Sankhla B, Sharma A, Shetty RS, Bolla SC, Gantha NS, Reddy P. Exfoliative cytology of buccal squames: A quantitative cytomorphometric analysis of patients with diabetes. J Int Soc Prev Community Dent. 2014 Sep;4(3):1827. doi: 10.4103/2231-0762.142024.

9. Rahmadwati E, Naghdy G, Ross M, Todd C, Norachmawati E. Classification Cervical Cancer Using Histology Images. $2^{\text {nd }}$ International Congress CACS, AISC. 2011; 145:235-243.

10. Bancroft JD, Gamble M. Theory and practice of histological techniques. $6^{\text {th }}$ ed. London: Churchill Livingstone. 2008.

11. Anuradha A, Sivapathasundharam B. Image analysis of normal exfoliated gingival cells. Indian J Dent Res. 2007 AprJun;18(2):63-6. doi: 10.4103/0970-9290.32422.

12. Patel PV, Kumar S, Kumar V, Vidya G. Quantitative cytomorphometric analysis of exfoliated normal gingival cells. J Cytol. 2011 Apr;28(2):66-72. doi: 10.4103/09709371.80745.

13. Hwang LY, Ma Y, Benningfield SM, Clayton L, Hanson EN, Jay J, Jonte J, Godwin de Medina C, Moscicki AB. Factors that influence the rate of epithelial maturation in the cervix in healthy young women. J Adolesc Health. 2009 Feb;44(2):103110. doi: 10.1016/j.jadohealth.2008.10.006.

14. Rani M N D, Narasimha A, Kumar Ml H, Sr S. Evaluation of Pre-Malignant and Malignant Lesions in Cervico Vaginal (PAP) Smears by Nuclear Morphometry. J Clin Diagn Res. 2014 Nov;8(11):FC16-C19. doi: 10.7860/JCDR/2014/10367.5221. 15. McCann MF, Irwin DE, Walton LA, Hulka BS, Morton $\mathrm{JL}$, Axelrad CM. Nicotine and cotinine in the cervical mucus of smokers, passive smokers, and nonsmokers. Cancer Epidemiol Biomarkers Prev. 1992 Jan-Feb;1(2):125-9.

16. International Collaboration of Epidemiological Studies of Cervical Cancer, Appleby P, Beral V, Berrington de González A, Colin D, Franceschi S, Goodhill A, et al. Cervical cancer and hormonal contraceptives: collaborative reanalysis of individual data for 16,573 women with cervical cancer and 35,509 women without cervical cancer from 24 epidemiological studies. Lancet. 2007 Nov 10;370(9599):1609-21. doi: 10.1016/S0140-6736(07)61684-5.

17. International Collaboration of Epidemiological Studies of Cervical Cancer, Appleby P, Beral V, Berrington de González A, Colin D, Franceschi S, Goodill A, Green J, Peto J, Plummer M, Sweetland S. Carcinoma of the cervix and tobacco smoking: collaborative reanalysis of individual data on 13,541 women with carcinoma of the cervix and 23,017 women without carcinoma of the cervix from 23 epidemiological studies. Int J Cancer. 2006 Mar 15;118(6):1481-95. doi: 10.1002/ijc.21493. 18. Dunne EF, Unger ER, Sternberg M, McQuillan G, Swan DC, Patel SS, Markowitz LE. Prevalence of HPV infection among females in the United States. JAMA. $2007 \mathrm{Feb}$ 28;297(8):813-9. doi: 10.1001/jama.297.8.813. 